\title{
Distribution of planktonic crustaceans and its diurnal changes in a hypertrophic shallow lake: does the switch from turbid-water state to clear-water state matters?
}

\author{
Wojciech Pęczuła*, Tomasz Mieczan and Monika Tarkowska-Kukuryk \\ Department of Hydrobiology and Protection of Ecosystems, University of Life Science in Lublin, ul. Dobrzańskiego 37, 20-262 Lublin, \\ Poland
}

Received: 20 February 2017; Accepted: 8 September 2017

\begin{abstract}
The paper presents results of post hoc analysis of diurnal changes in the crustacean distribution along the horizontal transect in the shallow hypertrophic lake, which undergone a switch from turbid-water, phytoplankton-dominated state (chl- $a$ : $257.8 \pm 100.2 \mu \mathrm{g} \mathrm{dm}^{-3}$, Secchi depth: $0.17 \pm 0.02 \mathrm{~m}$ ) to clear-water plant-dominated state (chl- $a: 26.8 \pm 4.8 \mu \mathrm{g} \mathrm{dm}^{-3}$, Secchi depth: $1.03 \pm 0.29 \mathrm{~m}$ ). Changes in crustacean biomass were observed in two consecutive years during two July days (every sixth hour, starting with the noon) in three sampling sites (emergent macrophytes, submerged macrophytes and center), situated along the horizontal transect between the lake shore and the center of the lake. Analysis revealed that: (a) in turbid-water conditions crustaceans aggregated at night-time near the water surface, both in the littoral zone and the lake center; (b) in clear-water state a nocturnal increase in crustacean biomass was noted only in submerged macrophyte site, but concerned only cladocerans. In conclusion, we hypothesized that switch from phytoplankton-dominated to plant-dominated state effects in change of predator-avoidance strategy showed by planktonic crustaceans.
\end{abstract}

Keywords: hypertrophic lake / horizontal distribution / planktonic crustaceans

\section{Introduction}

Heterogeneous distribution of zooplankton in lake ecosystems is a well-known phenomenon, studied since the end of the 19th century (i.e. Reighard, 1894; Ward, 1896). A lot of studies had been focused on physical forces which triggered this heterogeneity, but in the last decades, researchers have shown an increased interest in behavioural factors related to trophic interactions within a lake ecosystem (Burks et al., 2002). From this point of view, zooplankton spatial distribution is considered as an effect of compromise between finding an optimal place for development (including feeding) and the avoidance of being grazed by predators (Lampert, 1993; Lauridsen et al., 1996; Scheffer, 1998). This space pattern can be visible both in deep and shallow lakes, however, the mechanism responsible for this phenomenon may be different in those ecosystems. In deep lakes, planktonic crustaceans undertake vertical migrations into deeper and colder hypolimnetic water, thus avoiding visual predators in darker layers, which in turn effects in more dense population found during a day in hypolimnion (O'Brien and deNoyelles, 1972; Lampert, 1993). The absence of hypolimnetic refuge in shallow lakes

*Corresponding author: wojciech.peczula@up.lublin.pl makes vertical movements less advantageous for some zooplankters, thus to avoid grazing in daytime, they may undertake horizontal migrations (DHM) into vegetated littoral zones (Timms and Moss, 1984; Lauridsen and Buenk, 1996; Lauridsen et al., 1998). Submerged macrophytes are considered more profitable as refuges for zooplankton in comparison with emergent species as they may provide optimal shelter due to its structural complexity (Dionne and Folt, 1989; Venugopal and Winfield, 1993; Burks et al., 2002), although there are also reports that helophytes may play such role in turbid and eutrophic lakes (Nurminen et al., 2001; Cazzanelli et al., 2008). However, macrophyte zone serves as a refuge for juvenile planktivorous fish or a habitat for invertebrate predators, thus decreasing refuge capacity of macrophytes for zooplankton due to the increased predation risk, which may be observed as "shore avoidance" behaviour in some crustacean species (Carpenter and Lodge, 1986; Kornijów and Kairesalo, 1994; Gauthier and Boisclair, 1997; Lauridsen et al., 1999; Compte et al., 2016). Moreover, recent experimental research revealed, that when exposed to predation risk, large crustaceans prefer rather to moved away from the plants towards the sediments, which may serve as a better shelter (Tavsanoglu et al., 2012).

The occurrence of zooplankton DHM is strongly shaped by lake trophic conditions and biocoenosis structure (Burks et al., 
Table 1. Basic water quality parameters of lake Syczyńskie in summer 2006 and 2007.

\begin{tabular}{lll}
\hline & 2006 & 2007 \\
\hline Submerged macrophytes biomass $\left(\mathrm{g} \mathrm{FW} \mathrm{m}^{-2}\right)$ & 386.3 & 1440.6 \\
Transparency $(\mathrm{m})$ & $0.17 \pm 0.02$ & $1.03 \pm 0.29$ \\
Chlorophyll- $a\left(\mu \mathrm{g} \mathrm{dm}^{-3}\right)$ & $257.8 \pm 100.2$ & $26.8 \pm 4.8$ \\
$\mathrm{TP}\left(\mathrm{mg} \mathrm{dm}^{-3}\right)$ & $0.146 \pm 0.044$ & $0.104 \pm 0.019$ \\
$\mathrm{pH}$ & $7.8 \pm 0.3$ & $6.5 \pm 0.2$ \\
$\mathrm{EC}\left(\mu \mathrm{S} \mathrm{cm}^{-1}\right)$ & $326.6 \pm 10.8$ & $435.0 \pm 1.0$ \\
$\mathrm{P}-\mathrm{PO}_{4}\left(\mathrm{mg} \mathrm{dm}^{-3}\right)$ & $0.100 \pm 0.006$ & $0.167 \pm 0.045$ \\
$\mathrm{~N}-\mathrm{NO}_{3}\left(\mathrm{mg} \mathrm{dm}^{-3}\right)$ & $0.065 \pm 0.052$ & $0.041 \pm 0.013$ \\
$\mathrm{~N}-\mathrm{NH}_{4}\left(\mathrm{mg} \mathrm{dm}^{-3}\right)$ & $0.428 \pm 0.164$ & $0.109 \pm 0.091$ \\
\hline
\end{tabular}

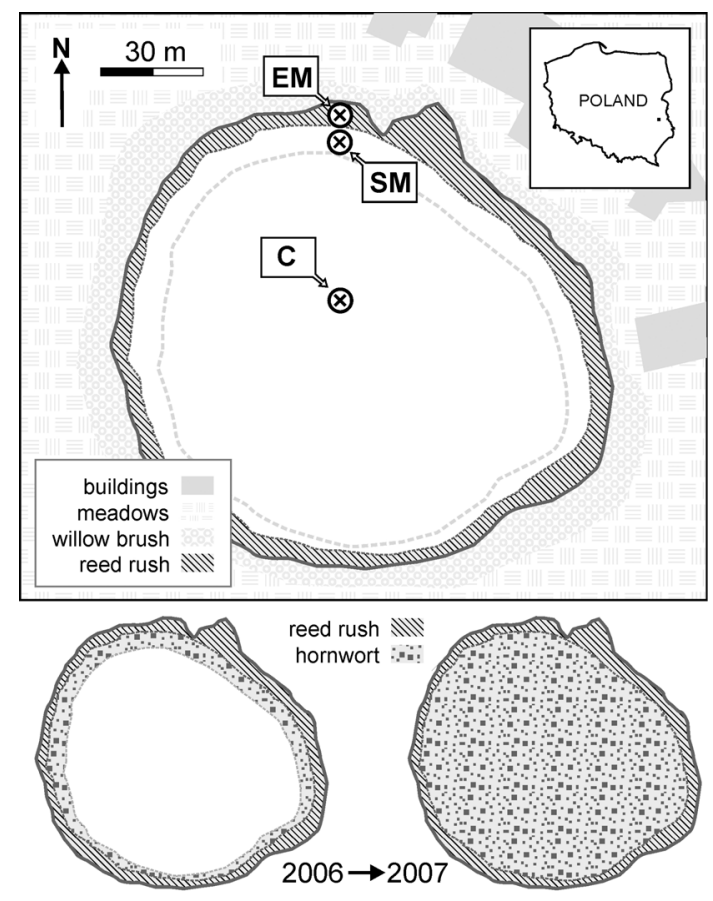

Fig. 1. Sampling points in lake Syczyńskie and the situation of studied lake in Poland (upper drawing); EM - emergent macrophytes, SM - submerged macrophytes, C - lake center. Lower drawings show the range of hornwort beds in 2006 and 2007.

2002). Generally, in turbid-water conditions rather small biomass of filter-feeding crustaceans is expected, due to its decreased filtration capacity (Dawidowicz, 1990; Gliwicz, 1990) but also a high density of non-organic particles suppress zooplankton development (Nurminen et al., 2001). Low water transparency reduces submerged macrophyte growth, thus the plant refuge may physically do not exist, moreover, high water turbidity may also lower fish predation on crustaceans, although fish abundance in these lakes is often sufficient to negate any refuge effect (Jeppesen et al., 1999). Low water transparency induced by humic substances may also shape the predatory-prey relations influencing the migratory behaviour of crustacean zooplankton (Estlander et al., 2017). DHM are generally favoured in shallow lakes with high macrophyte density and predatory fish population in the littoral zone, sufficiently abundant to control planktivore fish or restrict their habitat to open water (Burks et al., 2002). That is probably the main reason that more visible heterogeneity in the daytime zooplankton horizontal distribution is found in eutrophic lakes in respect to oligotrophic and mesotrophic ecosystems (Visman et al., 1994; Smiley and Tessier, 1998; Lauridsen et al., 1999).

Diurnal changes in the zooplankton horizontal distribution in shallow lake ecosystems are well documented (Fairchild, 1981; Timms and Moss, 1984; Davies, 1985; Difonzo and Campbell, 1988; Lauridsen and Buenk, 1996; Lauridsen et al., 1996, 1999; Stansfield et al., 1997; Cerbin et al., 2003; Cazzanelli et al., 2008). Most studies usually concerned zooplankton changes observed in eutrophic lakes with stable, plant-dominated conditions. A comparative research, carried out in one lake with two trophically differentiated basins (hypertophy vs. mesotrophy) was presented by Nurminen and Horppila (2002), although the study concerned a deep lake. To date, there has been no research applied to zooplankton distribution changes in nutrient-rich shallow lake ecosystem undergoing switch between turbid-water and clear-water conditions, which is considered as one of the major concepts of the alternative stable states theory (Scheffer et al., 1993).

Our study is based on research data collected during two consecutive summers in a hypertrophic shallow lake. During the first year we investigated diel changes in crustacean distribution along the horizontal transect in the lake suffering from cyanobacterial blooms. After first study, a rapid improvement of water quality had been noted in the next year, which created an opportunity to undertake a comparative research on crustacean distribution in changed conditions. Thus, the paper presents the results of post hoc analysis of data collected in two consecutive years, with the main aim to find differences between crustacean distribution patterns along the horizontal transect, before and after the switch from turbidwater, phytoplankton-dominated state to clear-water plantdominated state in a hypertrophic shallow lake.

\section{Material and methods}

The study of diurnal changes in horizontal distribution of crustacean plankton was conducted twice in two consecutive years in August 2006 and 2007 in shallow (mean depth $0.9 \mathrm{~m}$ ) and small (area 5.6 ha) lake Syczyńskie $\left(51^{\circ} 17^{\prime} 13^{\prime \prime} \mathrm{N}\right.$; $23^{\circ} 14^{\prime} 15^{\prime \prime}$ E; Eastern Poland). Since 2000-2001, the lake is regarded as hypertrophic, with low water transparency 


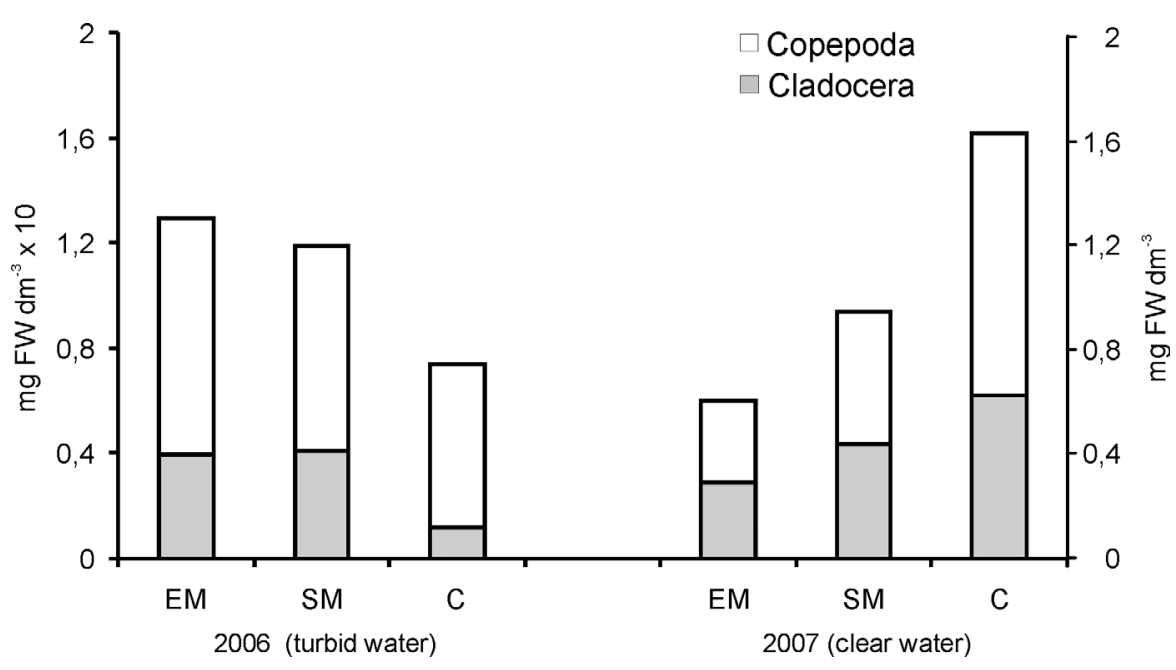

Fig. 2. Average fresh biomass of copepods and cladocerans in three sites in lake Syczyńskie during the study in 2006 and 2007 (sampling points abbreviations as in Fig. 1; note that on left $Y$ axis the values are ten-fold higher in comparison to right $Y$ axis).

$(<0.5 \mathrm{~m})$ and high total phosphorus level $\left(>0.1 \mathrm{mg} \mathrm{P} \mathrm{dm}^{-3}\right)$ which is reflected in virtually no submerged macrophytes and permanent blooms of filamentous cyanobacteria (Kornijów and Pęczuła, 2005). It is an effect of very high phosphorus load to the lake $\left(3.2 \mathrm{~g} \mathrm{P} \mathrm{m}^{-2}\right.$ year $\left.{ }^{-1}\right)$, related to unfavourable catchment conditions (Smal et al., 2005; Dawidek et al., 2009). Moreover, carbonate rocks which are present in the catchment area, determine high calcium and bicarbonate content of its waters (Dawidek et al., 2009), which is shown in high electrolytic conductivity and $\mathrm{pH}$ (EC: $394-610 \mu \mathrm{S} \mathrm{cm}^{-1}, \mathrm{pH}$ : 7.1-8.6; range in the period 2006-2007, after Toporowska and Pawlik-Skowrońska, 2014). Despite the fact that the lake is hypertrophic, perch (Perca fluviatilis) was a dominating species between 2006 and 2010 (Rechulicz, 2014).

In 2007 a rapid improvement of water quality had been noted: water transparency increased, chlorophyll- $a$ concentration decreased and dense beds of hornwort (Ceratophyllum demersum L.) appeared, although the total phosphorus concentration remained high (Tab. 1). Also, the change in the structure and abundance of phytoplankton was observed: very numerous cyanobacteria $\left(>100 \times 10^{6}\right.$ individuals $\left.\mathrm{dm}^{-3}\right)$ with Planktothrix aghardii as dominant in 2006 had been replaced in 2007 by greens with ten-fold lower abundance (Toporowska and Pawlik-Skowrońska, 2014). Fish structure changed from co-domination of perch and bleak in 2006 to the community dominated only by perch in 2007 (Rechulicz, 2014). What is interesting, the specimens of both species were small-sized (perch: $10.3 \pm 4.6 \mathrm{~cm}$, bleak: $6.2 \pm 0.6 \mathrm{~cm}$, data for the period 2006-2010). Differences between 2006 and 2007 in fish quantity were also noted: while total fish abundance was similar in both years ( $c a .100$ individuals net ${ }^{-1} 12 \mathrm{~h}^{-1}$, median), during clear-water conditions (2007) the total biomass was twice as much higher: $2200 \mathrm{~g} \mathrm{net}^{-1} 12 \mathrm{~h}^{-1}$ (median) against $1000 \mathrm{~g} \mathrm{net}^{-1} 12 \mathrm{~h}^{-1}$ (median) the previous year with turbidwater state (Rechulicz, 2014).

The reasons of the observed change remains unclear to us. According to interviews with local inhabitants and fishermen the lake was "treated with lime", which, in our opinion, may denote the addition of calcium carbonate as this compound is most often used in fish ponds in Poland. However, the effect of this "wild" restoration was short-lasting: in subsequent years (2008-2009) the cyanobacterial blooms recurred, effecting in low water transparency and high chlorophyll- $a$ level (Toporowska and Pawlik-Skowrońska, 2014).

Water for zooplankton analyses were collected from the surface level $(0.0-0.4 \mathrm{~m})$ with the use of Ruttner-type sampler ( $0.4 \mathrm{~m}$ of length, $5 \mathrm{dm}^{3}$ of volume) in three sites: "EM" emergent macrophytes (water column depth: $0.6 \mathrm{~m}$ ), "SM" submerged macrophytes (water column depth: $1 \mathrm{~m}$ ), and "C" center (water column depth: $2 \mathrm{~m}$ ) situated along the horizontal transect (north-south) between the lake shore and the center of the lake (Fig. 1). SM site was in $c a .15 \mathrm{~m}$ distance from the EM site and $c a .50 \mathrm{~m}$ distance from the $\mathrm{C}$ site. The emergent macrophytes site was overgrown by dense reed rush (Phragmites australis (Cav.) Trin. ex Steud) in both years. The submerged macrophytes site was composed of hornwort (C. demersum L.) beds on the bottom, which were sparse

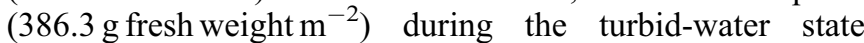
(2006). After the water quality had improved, the hornwort beds became very dense $\left(1440.6 \mathrm{~g}\right.$ fresh weight $\left.\mathrm{m}^{-2}\right)$ and covered almost all the lake bottom, including "SM" and "C" site (Fig. 1). In 2007 also sago pondweed (Stuckenia pectinata (L.) Börner) appeared on the lake bottom, but its biomass not exceeded $5 \%$ of that of hornwort.

Samples were taken during still and sunny weather in three random replicates every sixth hour, starting with the noon at: 00.00, 06.00, 12.00 and 18.00. Sunrise in August in the studied area is about at 05.00 and sunset at 20.00, thus sampling hours represented approximately: middle of the night, one hour after sunrise, middle of the day, two hours before sunset. In every of stations we made three replicate samplings in randomly chosen places, within the area of few square meters. For the analysis $10 \mathrm{dm}^{3}$ of water was filtered with plankton net of $55 \mu \mathrm{m}$ mesh and reduced to the volume of $0.1 \mathrm{dm}^{3}$. Crustaceans were counted using an inverted microscope according to Utermöhl's method (1958). Cladocerans were determined to the species level with the use of the key by Rybak and Błedzki (2010), while copepods were counted only with the distinction between adults and nauplii. The calculation of fresh weight was based on standards proposed by Hillbricht-Ilkowska and 
Table 2. Results of one-way ANOVA, differences between total crustacean biomass in sampling sites in 2006 and $2007(N=12, \mathrm{dF}=23, F$ critical $=4.30$ for $p<0.01)$.

\begin{tabular}{lllll}
\hline & \multicolumn{2}{c}{2006} & & \multicolumn{2}{c}{2007} \\
\cline { 2 - 5 } & $F$ & $P$ & $F$ & $p$ \\
\hline SM-EM & 0.11 & 0.738 & 4.26 & 0.037 \\
EM-C & 1.54 & 0.227 & 27.01 & $\mathbf{0 . 0 0 2}$ \\
SM-C & 0.81 & 0.376 & 8.74 & $\mathbf{0 . 0 0 7}$ \\
\hline
\end{tabular}

Patalas (1967). In order to determine the significance of differences among the zooplankton biomass samples, one-way ANOVA analysis with Tukey's test was performed using Statistica 6.0 software (Statsoft Inc., USA).

\section{Results}

The total crustacean fresh biomass in the studied lake differed between two consecutive summers in 2006 and 2007. In the first year (turbid-water conditions) the average biomass during sampling amounted $10.54 \pm 11.2$ (range: 0.71-39.45) $\mathrm{mg}$ fresh weight $(\mathrm{FW}) \mathrm{dm}^{-3}$ while in next year (clear-water conditions) was ten-fold lower $-1.06 \pm 0.7$ (range: $0.26-$ 3.07) $\mathrm{mg} \mathrm{FW} \mathrm{dm}^{-3}$ (Fig. 2). The statistical difference between crustacean biomass in two studied years was significant $(N=36, F=25.4, p<0.001)$. In 2006 the average biomass in lake center $\left(7.42 \pm 8.1 \mathrm{mg} \mathrm{FW} \mathrm{dm}^{-3}\right)$ site was lower in comparison to both macrophyte sites (SM: $11.22 \pm 12.1 \mathrm{mg}$ FW dm ${ }^{-3}$, EM: $12.97 \pm 13.1 \mathrm{mg} \mathrm{FW} \mathrm{dm}^{-3}$ ) although the difference was not statistically significant. In contrast, in the second year the crustacean biomass in lake center $\left(1.73 \pm 0.2 \mathrm{mg} \mathrm{FW} \mathrm{dm}^{-3}\right)$, was significantly higher than in both macrophyte sites (Tab. 2).

In 2006 copepods prevailed in total crustacean biomass, having an average share of $65-70 \%$ in macrophyte sites and even $83 \%$ in lake center site. The cladoceran taxonomical structure was very poor in both years and consist with two dominant species: Daphnia cucullata (which was the most numerous) and Bosmina longirostris. Additionally Chydorus sphaericus and Ceriodaphnia quadrangula were present with very small numbers in some samples. In next year the crustacean structure was more balanced with more or less equal share of copepods and cladocerans.

In the first year of the study (turbid-water conditions) we observed clear diurnal change in crustacean distribution (both cladocerans and copepods), however, it concerned rather the difference between day and night than changes along the horizontal transect. At noon and at late afternoon the total crustacean biomass in all three sampling points was low and comprised in the range $0.05 \pm 0.1-1.92 \pm 1.7 \mathrm{mg} \mathrm{FW} \mathrm{dm}^{-3}$ for cladocerans and $3.1 \pm 0.4-3.04 \pm 2.3 \mathrm{mg} \mathrm{FW} \mathrm{dm}^{-3}$ for copepods. At midnight we observed significant (Figs. 3 and 4, Tab. 3 ) increase of the biomass in all sites, which reached the values $3.81 \pm 0.1-12.46 \pm 3.6 \mathrm{mg} \mathrm{FW} \mathrm{dm}^{-3}$ for cladocerans and $15.90 \pm 4.4-22.18 \pm 2.2 \mathrm{mg} \mathrm{FW} \mathrm{dm}^{-3}$ for copepods. In case of cladoceran species the biomass increase was more distinct in both macrophyte sites in comparison to the lake center. One hour after sunrise the biomass significantly decreased ( $p$ $<0.01$ or $p<0.05$, Figs. 3 and 4, Tab. 3 ) in all sampling points, but still was predominantly higher in comparison to previous day values.

In the second year of the study (clear-water conditions) changes in crustacean biomass between sites and hours were less visible and more site-specific (Figs. 3 and 4). In emergent macrophytes no significant change during the study was observed, the cladoceran and copepod biomass was low and not higher than $0.39 \pm 0.2 \mathrm{mg} \mathrm{FW} \mathrm{dm}^{-3}$ (cladocerans) or $0.48 \pm 0.1 \mathrm{mg} \mathrm{FW} \mathrm{dm}^{-3}$ (copepods). Similar trend was noted in $\mathrm{C}$ site, however the biomass was slightly higher (cladocerans: $0.36 \pm 0.2-0.76 \pm 0.1 \mathrm{mg} \mathrm{FW} \mathrm{dm}^{-3}$, copepods: $0.59 \pm 0.1-1.70 \pm 0.4 \mathrm{mg} \mathrm{FW} \mathrm{dm}^{-3}$ ) and some increase (although not significant, Tab. 3) in copepod biomass could be observed between 0.00 and 06.00 hours. Similar to EM site values were observed in submerged macrophytes at noon and in the afternoon, but at midnight the cladoceran biomass significantly (Tab. 3) increased and reached $0.95 \pm 0.4 \mathrm{mg} \mathrm{FW}$ $\mathrm{dm}^{-3}$, then decreased after the sunrise to $0.41 \pm 0.1 \mathrm{mgFW}$ $\mathrm{dm}^{-3}$. The copepod biomass in this site did not show similar changes, although the slight, but insignificant increase was observed between late afternoon and midnight.

\section{Discussion}

In the present study, we aimed to find differences between crustacean distribution patterns and its diurnal changes in a hypertrophic shallow lake undergoing a switch from phytoplankton-dominated state to plant-dominated state. First, we found that during turbid-water conditions a crustacean biomass was almost ten-fold higher than in macrophyte-dominated, clear-water conditions. We suppose that improved water quality in the studied lake (a "switch") was induced by restoration measures, probably by addition of calcium compounds. As reported by Leoni et al. (2007) calcium hydroxide addition in eutrophic lakes may significantly decrease zooplankton abundance, not to mention the fact that the algae-reducing effect is often short-lasting - which was observed in the studied lake in further research (Toporowska and Pawlik-Skowrońska, 2014). Hovewer, as far as we have no evidences of the use of calcium, it is only the supposition. We think, that significantly decreased crustacean biomass was likely affected by two factors, with increased predation pressure from fish being the first one. Although fish total abundance was similar in both years, its total biomass increased twofold in the second year, which indicates that perch specimens had increased individual mass due to more intensive grazing. The second one was the decrease of phytoplankton total biomass (which can be seen in almost tenfold reduction of chlorophyll- $a$ concentration) which had to result in the reduction of potential food source for crustaceans. 
turbid water
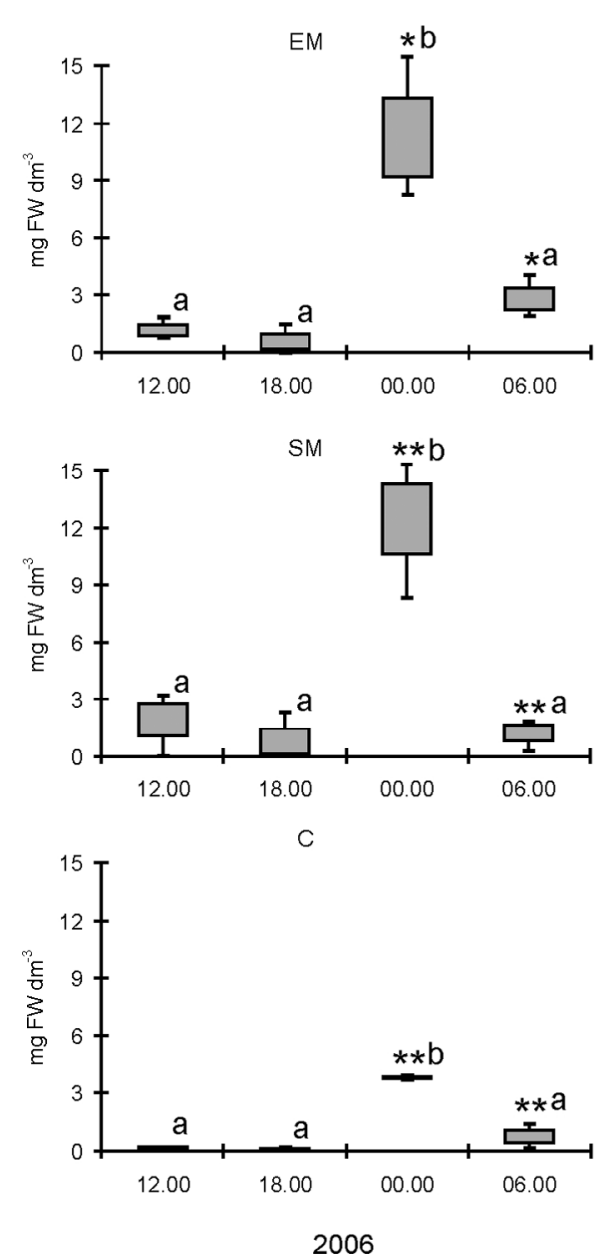

clear water
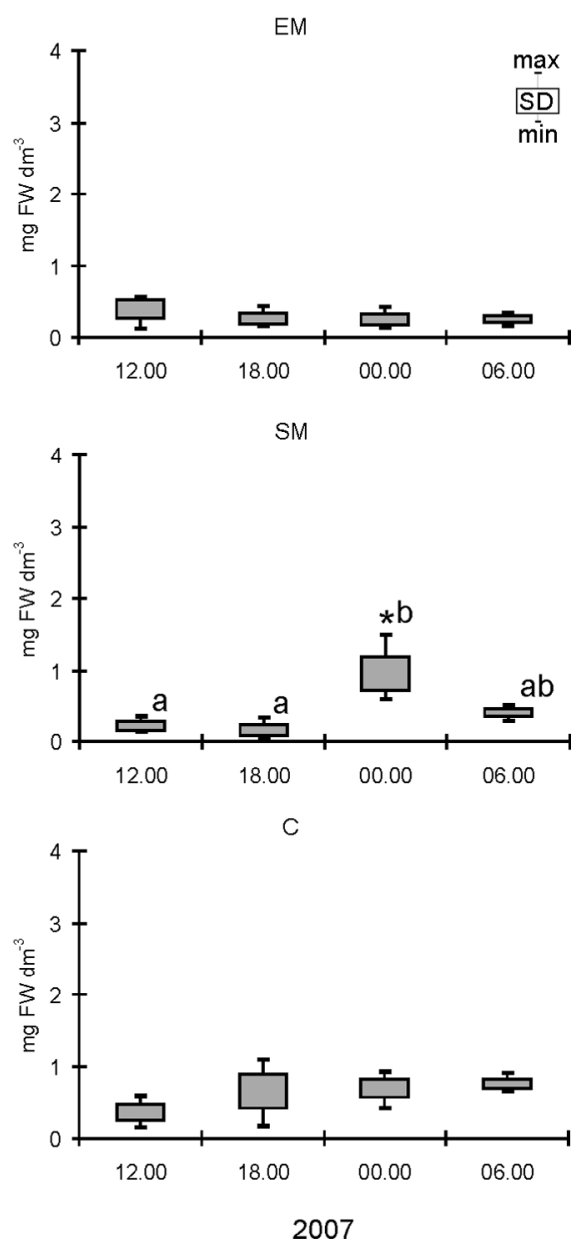

Fig. 3. Diurnal changes in planktonic cladoceran biomass (fresh=FW) in lake Syczyńskie in August 2006 and 2007 (sampling points abbreviations as in Fig. 1; asterisks show statistical significance in differences as compared to previous hour, $* p<0.05$, $* * p<0.01$, $\mathrm{SD}=$ standard deviation, samples marked with the same letters are not significantly different - results of Tukey's post hoc test).

In turbid-water year we did not observe significant differentiation in crustacean biomass along the horizontal transect, which suggest that either submersed nor emergent macrophytes didn't play a refuge role for zooplankton in such conditions. Some earlier reports suggested that helophytes may encourage crustacean aggregation within vegetation in the turbid-water, eutrophic lakes (Nurminen et al., 2001), although further studies showed that during cyanobacterial blooms this phenomenon didn't occur, probably due to cladoceran avoidance of unpropitious conditions (Nurminen and Horppila, 2002). In our study, a significant increase of the biomass was clearly visible in all sites at night. As our samples were taken from the surface layer $(0.0-0.4 \mathrm{~m})$, it might suggest that during a daytime crustaceans were clustered below euphotic layer, which came down to app. $0.4 \mathrm{~m}$ (water transparency in 2006: $0.17 \pm 0.02 \mathrm{~m}$ ). Aggregation of large zooplankton on or near the sediments during the day may be an effect of visual predators avoidance (DeStasio, 1993). Recent experimental studies showed, that Daphnia when exposed to predation risk preferred sediments as a shelter against predators, even in the presence of macrophytes (Tavsanoglu et al., 2012). Thus, our results showed that in turbid-water conditions in the shallow hypertrophic lake, small-scale diurnal vertical migrations may occur, a phenomenon which might be often underestimated due to the use of traditional zooplankton sampling methods, which avoid sediment (Burks et al., 2002). Some earlier studies reported crustacean DVM (nocturnal aggregation above macrophyte beds) occurring in shallow, plant-dominated lakes, even in a small depth water column of 1-2 m (Paterson, 1993; Gilbert and Hampton, 2001; Cerbin et al., 2003). However, in our study, nocturnal increase in crustacean biomass was noted even in sites with virtually no submersed macrophyte cover (lake center site), so it is likely that deeper layers and - because of high turbidity - dark layers played a daylight refuge role against population of small-sized, and probably planktivore perch and bleak. Thus, nightly crustacean migration upwards were likely forced by oxygen depletion, which might occur in hypertrophic lake in near-bottom layers (Burks et al., 2002). Although we had no oxygen data, it is known from other research, that in studied lake oxygen deficits occurred near the bottom layer in summer and during still weather (Kornijów, personal communication). 
turbid water
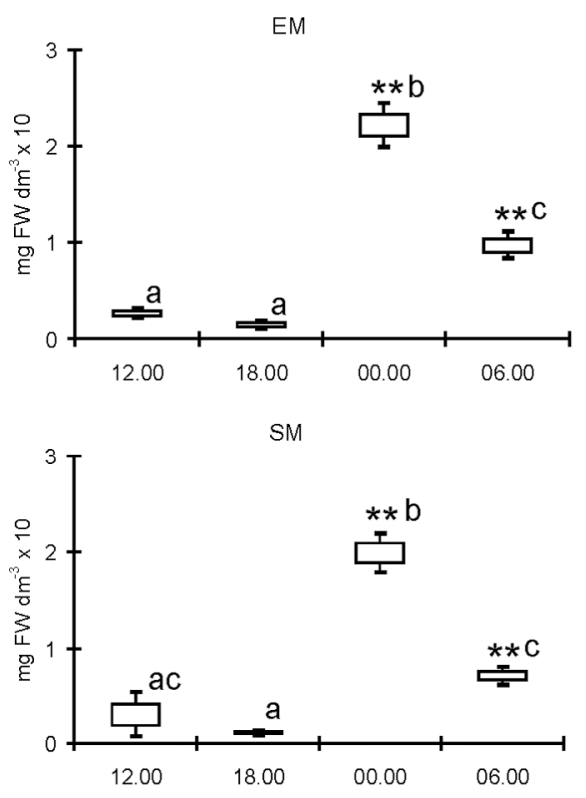

C

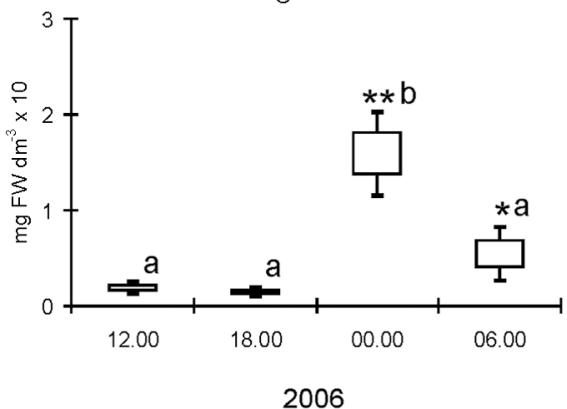

clear water
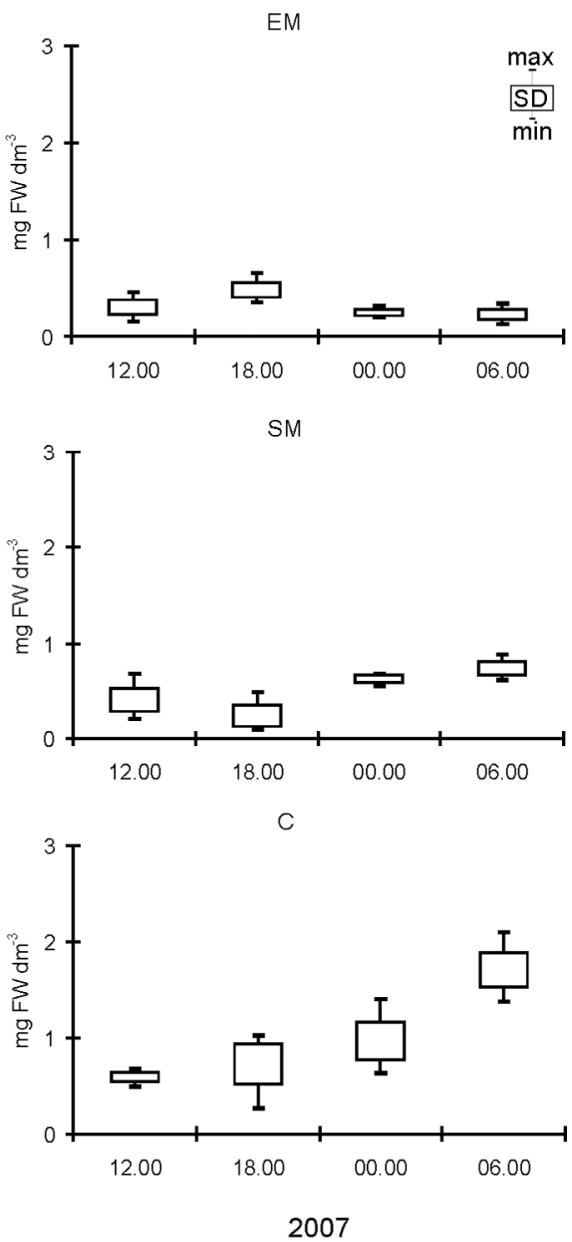

Fig. 4. Diurnal changes in planktonic copepod biomass (fresh weight $=$ FW) in lake Syczyńskie in August 2006 and 2007 (sampling points abbreviations as in Fig. 1; asterisks show statistical significance in differences as compared to previous hour, $* p<0.05$, $* * p<0.01$; $\mathrm{SD}=$ standard deviation, samples marked with the same letters are not significantly different - results of Tukey's post hoc test).

Table 3. Results of one-way ANOVA, differences in the biomass of cladocerans and copepods between sampling hours $(\mathrm{A}=12.00-18.00$, $\mathrm{B}=18.00-0.00, \mathrm{C}=0.00-6.00 ; N=3, \mathrm{dF}=5, F$ critical $=21.0$ for $p<0.01$ ).

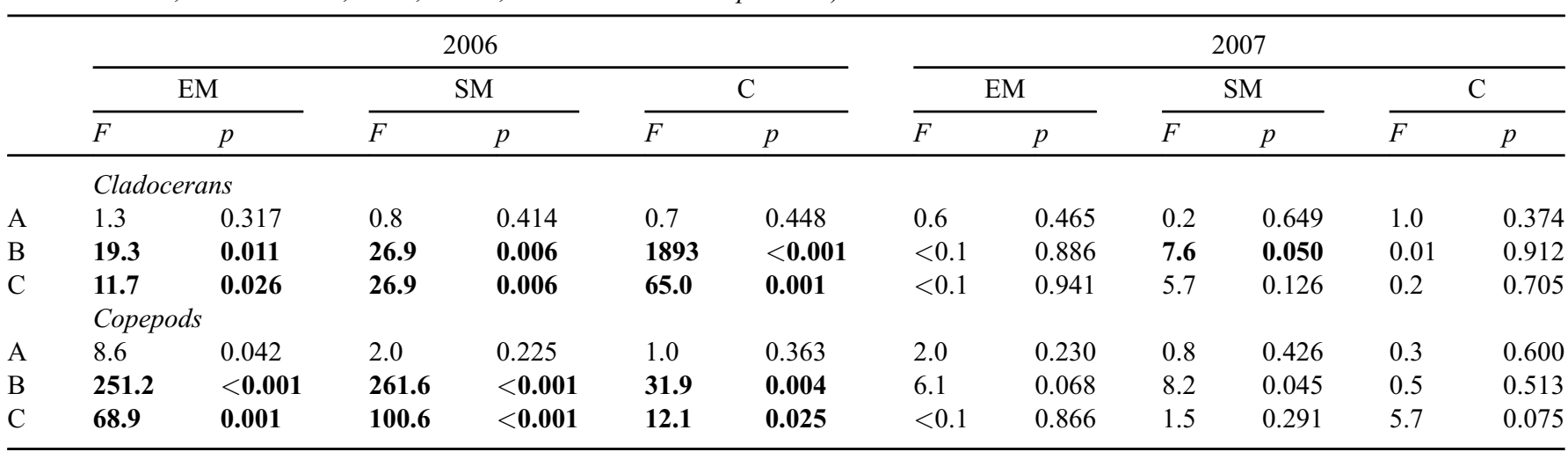

The second year study showed a different pattern in the diurnal crustacean distribution. At ten-fold lower crustacean biomass, but higher small-size perch biomass, we observed cladoceran (D. cucullata, B. longirostris) aggregation at midnight, but only in submersed macrophyte site. It suggests that after switch from phytoplankton-dominated state to macrophyte-dominated state, which effected in the increase of predator pressure on crustaceans, dense hornwort beds might 
play a role of daylight refuge in the studied lake, rather than water turbidity. It is in agreement with reports of Paterson (1993) and Cerbin et al. (2003) which revealed that in shallow lakes, some crustacean species (including $B$. longirostris) which used plant beds as refuge in daylight, migrate during night vertically to the open water above it. However, in contradiction to Paterson (1993) we did not observe clear change in copepod biomass (it was only slightly and insignificantly increased at night). However, the increased density of cladocerans in submerged macrophyte site may be also an effect of "reverse diel horizontal migrations", which may occur in shallow ponds (Compte et al., 2016). In this model, cladocerans avoid areas of high macrophyte densities during a daytime, due to increased predation risk from juvenile planktivorous fish or invertebrates, but at night they were more abundant in these habitats. From the same reason, a "shore avoidance" behaviour in crustaceans was observed in some studies concerning shallow lake ecosystems (Lauridsen et al., 1999). The lack of day/night changes in copepods in our study may be thus very similar to the observations made by Compte et al. (2016) which explained the lack of reverse horizontal migrations in some copepods by relatively low efficiency in capturing copepods by invertebrate predators in macrophytic habitats.

In conclusion, our study showed that a switch from turbidwater to clear-water in a shallow hypertrophic lake strongly influences the distribution pattern of planktonic crustaceans and its diurnal changes. It may be hypothesized that high water turbidity in shallow lakes favour vertical movements of planktonic crustaceans, which use the layer below the euphotic zone as refuges, a phenomenon known from deep lakes. After the switch to clear-water state occurred, crustaceans change their predator-avoidance strategy and hide at daylight in submerged macrophytes, a phenomenon well-known in shallow, plant-dominated lakes. However, our findings must be interpreted with caution because of low resolution sampling, which didn't include samples from the bottom layers, thus the evidence and conclusions are rather indirect. Nevertheless, as it was the first study comparing crustacean distribution upon radical change conditions, it extends our knowledge on shallow hypertrophic lakes and may serve as a base for future studies on crustacean functioning in this type of ecosystem.

Acknowledgements. The authors want to thank Prof. Ryszard Kornijów for conceptual support in the study as well as Joanna Wolińska and Paweł Sankowski for the help in the field work.

\section{References}

Burks RL, Lodge DM, Jeppesen E, Lauridsen TL. 2002. Diel horizontal migration of zooplankton: costs and benefits of inhabiting the littoral. Freshw Biol 47: 343-365.

Carpenter SR, Lodge DM. 1986. Effects of submerged macrophytes on ecosystem processes. Aquat Bot 26: 341-370.

Cazzanelli M, Warming TP, Christoffersen KS. 2008. Emergent and floating-leaved macrophytes as refuge for zooplankton in a eutrophic temperate lake without submerged vegetation. Hydrobiologia 605: 113-122.

Cerbin S, Balayla DJ, Van de Bund WJ. 2003. Small-scale distribution and diel vertical migration of zooplankton in a shallow lake (Lake Naardermeer, the Netherlands). Hydrobiologia 491: 111-117.
Compte J, Montenegro M, Ruhí A, Gascón S, Sala J, Boix D. 2016. Microhabitat selection and diel patterns of zooplankton in a Mediterranean temporary pond. Hydrobiologia 766: 201-213.

Davies J. 1985. Evidence for a diurnal horizontal migration in Daphnia hyalina lacustris Sars. Hydrobiologia 120: 103-105.

Dawidek J, Pęczuła W, Ferencz B. 2009. The role of catchment and in-lake processes in shaping trophic conditions of the shallow lake Syczyńskie (Eastern Poland). Ecohydrol Hydrobiol 9: 193-200.

Dawidowicz P. 1990. Effectiveness of phytoplankton control by large-bodied and small-bodied zooplankton. Hydrobiologia 200/ 201: 43-47.

DeStasio BT. 1993. Diel vertical and horizontal migration by zooplankton: population budgets and the diurnal deficit. Bull Mar Sci 53: 44-64.

Difonzo CD, Campbell JM. 1988. Spatial partioning of microhabitats in littoral cladoceran communities. J Freshw Ecol 4: 303-313.

Dionne M, Folt CL. 1989. An experimental analysis of macrophyte growth forms as fish foraging habitat. Can J Fish Aquat Sci 48: 123-131.

Estlander S, Horppila J, Olin M, Nurminen L. 2017. Should I stay or should I go? The diurnal behaviour of plant-attached zooplankton in lakes with different water transparency. J Limnol. 76: 253-260.

Fairchild GW. 1981. Movement and microdistribution of Sida crystallina and other littoral microcrustacea. Ecology 62: 1341-1352.

Gauthier S, Boisclair D. 1997. The energetic implications of diel onshore-offshore migration by dace (Phoxinus eos $x$ P. neogaetus) in a small oligotrophic lake. Can J Fish Aquat Sci 54: 1996-2006.

Gilbert JJ, Hampton SE. 2001. Diel vertical migrations of zooplankton in a shallow, fishless pond: a possible avoidance-response cascade induced by notonectids. Freshw Biol 46: 611-621.

Gliwicz ZM. 1990. Why do cladocerans fail to control algal blooms? Hydrobiologia 200/201: 83-97.

Hillbricht-Ilkowska A, Patalas K. 1967. Metody oceny produkcji biomasy oraz niektóre problemy metodyki ilos ciowej zooplanktonu. Ekol Pol B 13: 139-172.

Jeppesen E, Søndergaard M, Kronvang B, Jensen JP, Svendsen LM, Lauridsen T. 1999. Lake and catchment management in Denmark. In Harper D, Ferguson A, Brierley B, Phillips G, eds. Ecological basis for lake and reservoir management. Hydrobiologia 395/396: 419-432.

Kornijów R, Kairesalo T. 1994. A simple apparatus for sampling epiphytic communities associated with emergent macrophytes. Hydrobiologia 294: 141-143.

Kornijów R, Pęczuła W. 2005. Ecosystem of a small and shallow lake suffering from cyanobacterial blooms - hypereutrophic, phytoplankton-dominated or both? Internationale Vereinigung fur Theoretische und Angewandte Limnologie Verhandlungen 29: 1015-1019.

Lampert W. 1993. Ultimate causes of diel vertical migration of zooplankton: new evidence for the predator-avoidance hypothesis. Archiv fur Hydrobiologie Ergebnisse der Limnologie 39: 79-88.

Lauridsen TL, Buenk I. 1996. Diel changes in the horizontal distribution of zooplankton in the littoral zone of two shallow eutrophic lakes. Archiv fur Hydrobiologie 137: 167-176.

Lauridsen T, Pedersen LJ, Jeppesen E, Søndergaard M. 1996. The importance of macrophyte bed size for cladoceran composition and horizontal migration in a shallow lake. J Plankton Res 18: 2283-2294.

Lauridsen TL, Jeppesen E, Søndergaard M, Lodge D. 1998. Horizontal migration of zooplankton: predator-mediated use of macrophyte habitat. In Jeppesen E, Søndergaard Ma, Søndergaard 
Mo, Christoffersen K, eds. The structuring role of submerged macrophytes in lakes. New York: Springer Verlag, pp. 233-239.

Lauridsen TL, Jeppesen E, Mitchell SF, Lodge DM, Burks R L. 1999. Diel variation in horizontal distribution of Daphnia and Ceriodaphnia in oligotrophic and mesotrophic lakes with contrasting fish densities. Hydrobiologia 408/409: 241-250.

Leoni B, Moabito G, Rogora M, Pollastro D, Mosello D, Arisci S, Forasacco E, Garibaldi L. 2007. Response of planktonic communities to calcium hydroxide addition in a hardwater eutrophic lake: results from a mesocosm experiment. Limnology 8: $121-130$.

Nurminen LK, Horppila JA. 2002. A diurnal study on the distribution of filter feeding zooplankton: Effect of emergent macrophytes, $\mathrm{pH}$ and lake trophy. Aquat Sci 64: 198-206.

Nurminen L, Horppila J, Tallberg P. 2001. Seasonal development of the cladoceran assemblage in a turbid lake: the role of emergent macrophytes. Archiv für Hydrobiologie 151: 127-140.

O’Brien WJ, deNoyelles F. 1972. Photosynthetically elevated $\mathrm{pH}$ as a factor in zooplankton mortality in nutrient enriched ponds. Ecology 53: 605-614.

Paterson M. 1993. The distribution of microcrustacea in the littoral zone of a freshwater lake. Hydrobiologia 263: 173-183.

Rechulicz J. 2014. Long-term changes of the fish community in a small hypertrophic lake. Pol J Environ Stud 23: 845-851.

Reighard JE. 1894. A biological examination of lake St. Clair. Bull Michigan Fish Commission 4: 61.

Rybak JI, Błędzki LA. 2010. Słodkowodne skorupiaki planktonowe: klucz do oznaczania gatunków. Warszawa: Wydawnictwa Uniwersytetu Warszawskiego, p. 368 (in Polish).

Scheffer M. 1998. Community dynamics of shallow lakes. London: Chapman \& Hall, p. 357.

Scheffer M, Hosper SH, Meijer M-L., Moss B, Jeppesen E. 1993. Alternative equilibria in shallow lakes. Trends Ecol Evol 8: 275-279.
Smal H, Kornijów R, Ligęza S. 2005. The effect of catchment on water quality and eutrophication risk of five shallows lakes (Polesie Region, Eastern Poland). Pol J Ecol 53: 313-327.

Smiley EA, Tessier AJ. 1998. Environmental gradients and the horizontal distribution of microcrustaceans in lakes. Freshw Biol 39: 397-409.

Stansfield JH, Perrow MR, Tench LD, Jowitt AJD, Taylor AAL. 1997. Submerged macrophytes as refuge for grazing Cladocera against fish predation: observations on seasonal changes in relation to macrophyte cover and predation pressure. Hydrobiologia 342/343: 229-240.

Tavsanoglu ÜN, Çakiroglu AI, Erdogan S, Meerhoff M, Jeppesen E, Beklioglu M. 2012. Sediments, not plants, offer the preferred refuge for Daphnia against fish predation in Mediterranean shallow lakes: an experimental demonstration. Freshw Biol 4: 795-802.

Timms RM, Moss B. 1984. Prevention of growth of potentially dense phytoplankton populations by zooplankton grazing, in the presence of zooplanktivorous fish, in a shallow wetland ecosystem. Limnol Oceanogr 29: 472-486.

Toporowska M, Pawlik-Skowrońska B. 2014. Four-year study on phytoplankton biodiversity in a small hypertrophic lake affected by water blooms of toxigenic cyanobacteria. Pol J Environ Stud 23: 491-499.

Utermöhl H. 1958. Zur Vervollkomnung der qualitativen Phytoplanktonmetodik. Mitt Int Verein Limnol 9: 1-38.

Venugopal MN, Winfield IJ. 1993. The distribution of juvenile fishes in a hypereutrophic pond: can macrophytes potentially offer a refuge for zooplankton? J Freshw Ecol 8: 389-396.

Visman V, McQueen, DJ, Demers E. 1994. Zooplankton spatial patterns in two lakes with contrasting fish community structure. Hydrobiologia 284: 177-191.

Ward HB. 1896. A biological examination of Lake Michigan. Bull Michigan Fish Comm 6: 62-64.

Cite this article as: Peczuła W, Mieczan T, Tarkowska-Kukuryk M. 2017. Distribution of planktonic crustaceans and its diurnal changes in a hypertrophic shallow lake: does the switch from turbid-water state to clear-water state matters? Ann. Limnol. - Int. J. Lim. 53: 369-376 